\title{
Does soy increase blood counts in myelodysplastic syndromes?
}

\author{
Será que a soja aumenta as contagens sanguíneas em síndrome mielodisplásica?
}

T. A. O. F. Viana'; E. Claricia'; R. F. Pinheiro'; M. C. C. Panizzi²; A. F. Sandes'; V. M. Carvalho'; R. C. C. Sesso'; M. Yamamoto'; A. N. Atallah ${ }^{4}$; M. L. L. F. Chauffaille ${ }^{1}$

\begin{abstract}
key words abstract
Soy

White blood counts

Myelodysplastic syndrome

Isoflavones

Hemoglobin

Platelet

Myelodysplastic syndromes (MDS) are a group of clonal stem cell diseases characterized by ineffective hematopoiesis, bone marrow hyperproliferation, cytopenias in peripheral blood and risk of transformation into acute leukemia. We decided to investigate the effects of a soy concentrate on MDS patients based on the follow-up results of a 61 year-old Japanese female patient who was diagnosed with MDS and refractory cytopenia with multilineage dysplasia in 2003 (hemoglobin = $11 \mathrm{~g} / \mathrm{dL}$; white blood cells count $=2,500 / \mathrm{uL}$ and platelets $=25,000 / \mathrm{uL}$; marrow with mild dysplasia and normal karyotype; paroxysmal nocturnal hemoglobinuria was excluded). She started using soy as a dietary supplementation in May 2004 and presented a gradual increment in blood counts, achieving normalization approximately eight months afterwards. Among the soy components, the main compounds with anti-carcinogenic activity are the isoflavones (genistein and daidzein). Based on these lines of evidence, we proposed to administer daily a standard soy concentrate to 14 MDS out-patients for a minimum period of three months and maximum of 12 months, in an attempt to evaluate prospectively the possible increase in hemoglobin, neutrophils and platelet counts. A historical control group was used to compare results. The use of a soy concentrate in a standardized manner was associated with an increase in neutrophil and/or platelet counts in some cases, but spontaneous increments were also observed in historical controls. This preliminary study does not allow establishing a relation between soy supplementation and blood cell count increase.
\end{abstract}

resumo

As síndromes mielodisplásicas (SMD) são um grupo das doenças clonais de células-tronco caracterizado por hematopoese ineficaz, hiperproliferação de medula óssea, citopenias no sangue periférico e risco de transformação para leucemia aguda. Decidimos investigar os efeitos de um concentrado de soja em pacientes com SMD com base no fato de termos o seguimento de uma paciente japonesa, de 61 anos de idade, que foi diagnosticada em 2003 com SMD, citopenia refratária com displasia subtipo multilinhagens (hemoglobina $=11 \mathrm{~g} / \mathrm{dL}$; contagem de glóbulos brancos $=2.500 / \mathrm{LL}$ e plaquetas $=25.000 / \mathrm{LL}$; medula com displasia leve e cariótipo normal; hemoglobinúria paroxística excluída), e que começou a usar a soja como suplemento alimentar em maio de 2004, apresentando gradual aumento da contagem das células sanguíneas, atingindo a normalização cerca de oito meses depois. Entre os componentes da soja, os principais compostos com propriedades anticarcinogênese são as isoflavonas (Ge nisteína e daidzeína). Com base nessas linhas de evidência, foi proposto oferecer diariamente um concentrado de soja padrão, por um período mínimo de três meses e máximo de doze meses, a 14 pacientes ambulatoriais, na tentativa de avaliar, prospectivamente, o possivel aumento de hemoglobina, neutrófilos e plaquetas. Um grupo controle histórico foi utilizado para comparar os resultados. O uso de um concentrado de soja de forma padronizada foi associado ao aumento na contagem de neutrófilos e/ou de plaquetas em alguns casos, mas aumentos espontâneos também foram observados em controles históricos. Este estudo preliminar não permite estabelecer relação entre o uso de soja e o aumento na contagem sanguínea.

\section{unitermos}

Soja

Contagens sanguíneas

Síndrome mielodisplásica

Isoflavonas

Hemoglobina

Plaqueta

1. Disciplina de Hematologia e Hemoterapia da Escola Paulista de Medicina da Universidade Federal de São Paulo (UNIFESP).

2. Centro Nacional de Pesquisa de Soja da Empresa Brasileira de Pesquisa Agropecuária (EMBRAPA).

3. Instituto Fleury.

4. Departamento de Medicina da Escola Paulista de Medicina da UNIFESP. 


\section{Introduction}

Myelodysplastic syndromes (MDS) are a group of clonal diseases of hematopoietic stem cell characterized by ineffective production of blood cells, bone marrow hyperproliferation, cytopenias in peripheral blood and risk of transformation to acute myeloid leukemia (AML) in $30 \%$ of patients ${ }^{(3)}$. MDS are frequent in older people, with median age at diagnosis at Universidade Federal de São Paulo (UNIFESP) of 64 years-old ${ }^{(22)}$.

The first MDS classification was proposed by the FrenchAmerican-British (FAB) group in 1982 and included patients who had less than $30 \%$ of bone marrow blasts and evidences of ineffective hematopoesis at diagnosis ${ }^{(3)}$. The World Health Organization (WHO) modified the limit of blasts to $20 \%$ and re-classified the refractory anemia with excess of blasts in transformation group (RAEB-t) into acute leukemia (AL) ${ }^{(10)}$. According to the WHO, the subtypes of MDS are: refractory anemia (RA), 5q- syndrome, refractory anemia with ringed sideroblasts (RARS), refractory cytopenia with multilineage dysplasia (RCMD), refractory cytopenia with multilineage dysplasia and ringed sideroblasts (RCMD and RS), refractory anemia with excess of blasts I (RAEB-I), refractory anemia with excess of blasts II (RAEB-II) and MDS unclassifiable ${ }^{(10)}$.

In 1997, Greenberg et al. created an International Prognostic Scoring System (IPSS) to predict the risk of transformation to $\mathrm{AL}^{(8)}$. The variables included in this system are: karyotype, percentage of blasts in peripheral blood (PB) and number of cytopenias in PB. According to IPSS the patients are classified as low risk, intermediate 1, intermediate 2 and high risk.

The physiopathology of MDS is not well understood yet, but apparently it is due to accumulated genomic modifications that promote abnormalities in cell maturation and differentiation. Clonal expansion induces an ineffective hematopoesis that results in anemia, leukopenia or decreased platelet counts. There is an enhanced degree of apoptosis which contributes to the cytopenias. The evolution of the disease is marked by damaged maturation originating gradual excess of mieloblasts ${ }^{(11)}$. The therapeutic goal in low risk patients is to increase the hemoglobin, neutrophil and platelet counts in order to decrease transfusion needs and to avoid the incidence of bleeding or infections. In the high risk group the objective is to eliminate the abnormal clone ${ }^{(12,26)}$.

We decided to investigate the effects of a soy concentrate in MDS patients based on the fact of having followed-up a 61 year-old-female Japanese patient who was diagnosed with MDS, RCMD subtype, in 2003, $(\mathrm{Hb}=11 \mathrm{~g} / \mathrm{dL}$, white blood cell count $=2500 / \mu \mathrm{L}$ and platelets $=25.000 / \mu \mathrm{L}$, marrow aspiration and biopsy with mild dysplasia, compatible with MDS, marrow karyotype $=46, X X[20]$, and paroxistic nocturnal hemoglobinuria ruled out), and who started using soy as a dietary supplementation in May 2004 and presented a gradual increment of her blood counts, achieving normalization around eight months afterwards.

Experimental and epidemiological evidences suggest that a diet rich on soy products is associated with low cancer mortality, mainly neoplasia of breast and prostate ${ }^{(23)}$. Among the soy components, the main compounds with anti-carcinogenesis properties are the isoflavones (genistein and daidzein ${ }^{(15,20)}$ Isoflavones have a phenol group in their structures and belong to phytoestrogen $\operatorname{class}^{(7)}$.

Genistein is associated with the blockade of protein tyrosine-kinases activities and inhibition of topoisomerases enzyme II that participates in DNA replication, transcription and repair ${ }^{(1,2)}$. Genistein is also related with cell death induction in non-small-cell lung cancer (NSCLC) through a p53-independent pathway and, thus, may act as an anticancer agent ${ }^{(14)}$. High dose of genistein inhibits Caco-2BBe human intestinal cells by causing $\mathrm{G} 2 / \mathrm{M}$ cell cycle arrest $^{(5)}$. Genistein inhibits the growth of human breast and prostate cancer cells ${ }^{(17,18)}$. All of these characteristics result in main anti-carcinogenic effect, that blocks the cell growth, beyond stimulating apoptosis.

Daidzein has a blockade effect in cell cycle, anti-tumor activities on murine neuroblastoma cells and is responsible for decreasing the expression of telomerase enzyme in in vitro tests with cervix tumor cells $s^{(9,16)}$.

A detailed search was made in electronic database Pubmed using descriptive terms and synonymies for soy (intervention) and myelodysplastic syndrome (clinical situation) and no publication was found relating soy to MDS. A second search relating soy (intervention) with the following limits: clinical trial, phase I, clinical trial, phase II revealed use of isoflavones in postmenopausal women ${ }^{(4)}$.

Based on these lines of evidences, this study was designed to be a pilot one to find out if a soy supplement could produce an increase in hemoglobin, neutrophils or platelet counts in MDS patients who used a standard soy concentrate for a minimum of three-month time period and maximum of twelve months.

\section{Material and methods}

Fourteen patients with the diagnosis of MDS according to WHO classification ${ }^{(10)}$ were admitted to the study. Patients 
were selected from the out-patient clinics of Hematology Department of UNIFESP/Hospital São Paulo, from March 2006 till March 2008. Patients agreed to participate after informed consent as well as agreed to have blood samples collected for analysis whenever established by the protocol and to follow all the instructions for the preparation of the soy concentrate. The study was approved by the institution Ethics Committee (n. 1207/05).

The inclusion criteria were: MDS patients, at least three months after diagnosis (that means they were refractory to therapeutic tests with folic acid, $5 \mathrm{mg} /$ day; B12 vitamin, 5 million of units, and pyridoxine, $900 \mathrm{mg} /$ day for three months); not eligible for therapies like: hypomethylating agents, chemotherapy or other drugs; and classified as low to intermediate grade on prognosis (WHO and IPSS classifications).

The exclusion criteria were: Patients, who could not properly follow the orientations, refused to collect blood or were in use of growth factors like erythropoietin, filgastrine or similar ones.

Table 1 shows patients characteristics, like age, sex, MDS WHO subtype, IPSS classification, initial hemoglobin, neutrophil and platelet counts.

The following aspects were considered as response criteria $^{(6)}$ :

- $\quad$ erythroid response: for patients with pretreatment hemoglobin less than $11 \mathrm{~g} / \mathrm{dL}$, an increase in hemoglobin level of at least $1.0 \mathrm{~g} / \mathrm{dL}$ for three months in a sustained way; or for patients who were transfusion-dependent, a reduction in 50\% of transfusion needs;

- neutrophil response: for absolute neutrophil count less than $1500 / \mathrm{mm}^{3}$ before therapy, at least a $100 \%$ increase, or an absolute count of more than $500 / \mathrm{mm}^{3}$ for three months;

- platelet response: for patients with pretreatment platelet count less $100,000 / \mathrm{mm}^{3}$, a $50 \%$ or more increase in platelet count; or to become transfusion independent for those who were transfusiondependent.

The first evaluation was made at 3 months follow-up, and then at 6,9 and 12 months.

In order to have only one kind of soy used for the study, the soy used in the study was kindly provided by Empresa Brasileira de Pesquisa Agropecuária (EMBRAPA), and was of a special seed non-transgenic type (PGA 56.05 lot Ponta Grossa-PR, Rodovia do Talco km 03, registered
SEAG number 065), cultivated in a particular region in the South of Brazil, obtained from the same crop and harvest.

A standard recipe for the preparation of soy concentrate was provided; the patient was oriented to prepare it accordingly and to drink one liter of this concentrate daily for at least three months. The recipe was: put $500 \mathrm{~g}$ of soy seed into water and wait for 12 hours; take off the husk, put into a mixer, percolate and then seethe; add sugar or fruit pulp as wished. The prepared concentrate could be stored in a refrigerator and 1 liter of it should be drunk along the day.

A social assistant periodically visited the patient's home to check how the concentrate was being prepared and patient's compliance. Besides that, at each follow-up the patient was inquired about his adherence to the protocol by the investigators, and about side effects.

Before starting the use of soy concentrate each patient was submitted to the following tests: $\mathrm{Hb}$, white blood cells count (WBC) with cell differentiation and platelet count, which were repeated at each follow-up evaluation.

In each follow-up evaluation patients were questioned about symptoms or eventual side effects of the use of soy concentrate, were submitted to physical examination and blood tests, and transfusion needs were annotated.

A blood sample was collected for quantitation of total genistein and daidzein in serum by liquid chromatography coupled to tandem mass spectrometry (LC-MS/MS).

The internal standard (genistein- $d_{3}$ at $5 \mu \mathrm{g} / \mathrm{mL}$ prepared as described by Kiuru and Wähälä̈[13]) was added to $0.3 \mathrm{~mL}$ of serum plasma in a $1.5 \mathrm{~mL}$ polypropylene tube. This sample was treated with $0.25 \mathrm{~mL}$ of a mixture of $\beta$-glucuronidase/ sulfatase from Helix pomatia to hydrolyze glucuronide and sulfate conjugates of genistein and daidzein and 0.75 $\mathrm{mL}$ of $0.2 \mathrm{M} \mathrm{pH} 4.0$ acetate buffer ${ }^{(25)}$. The mixture was incubated overnight $(15-18 \mathrm{~h})$ at $37^{\circ} \mathrm{C}$. The digestion was stopped by the addition of $0.5 \mathrm{~mL}$ of $0.2 \mathrm{~mol} / \mathrm{L} \mathrm{ZnSO}_{4} /$ methanol (20/80) followed by vortexing for more $3 \mathrm{~min}$ and centrifugation for $10 \mathrm{~min}$ at $4000 \times \mathrm{g}$. The supernatant was transferred to a polypropylene 96-well deep well plate and placed in a Waters 2777 sample manager equipped with a cooling stack set at $10^{\circ} \mathrm{C}$.

One milliliter of the supernatants were on-line extracted using Onyx monolithic C18 $10 \times 4.6 \mathrm{~mm}$ cartridge (Phenomenex, Torrance, CA) connected to a 2-position, 6-port Phenomenex Synergi fluid processor. Samples were loaded and washed with $5 \%$ acetonitrile at $4 \mathrm{~mL} / \mathrm{min}$ pumped by a Waters 510 pump (Millford, MA) for 2 min. The analytes were eluted for $1.5 \mathrm{~min}$ on to a Synergi Fusion 
$4 \mu 50 \times 2 \mathrm{~mm}$ analytical column (Phenomenex) kept at $50^{\circ} \mathrm{C}$ in a Thermasphere TS- 130 column oven. The analytical column was eluted with a multistep binary gradient pumped by a Waters $1525 \mu$ pump. The elution mobile phase consisted initially of a mixture of $40 \%(\mathrm{v} / \mathrm{v})$ methanol in $0.5 \mathrm{mmol} / \mathrm{L} \mathrm{pH} 3.0$ ammonium formate at a flow rate of $0.3 \mathrm{~mL} / \mathrm{min}$. The methanol content was increased to $60 \%$ in 5 minutes using the binary gradient curve 6 and kept at $60 \%$ fir 2.5 minutes.

Detection was performed on a Quattro Premier tandem mass spectrometer (Waters, Manchester, UK) equipped with an electrospray probe operating at positive mode. The mass spectrometer operating conditions were as follows: desolvation temperature $400^{\circ} \mathrm{C}$, desolvation gas (nitrogen) flow $700 \mathrm{~L} / \mathrm{h}$, source temperature $80^{\circ} \mathrm{C}$, cone gas flow (nitrogen) $50 \mathrm{~L} / \mathrm{h}$, with capillary potential set to $3.5 \mathrm{kV}$. Collision-induced dissociation was performed using argon as the collision gas at $4 \times 10-3$ mbar. For product ion spectra and multiple reaction monitoring (MRM) analyses, unit resolution was maintained for both parent and product ions. Instrument optimization for the analytes were conducted by infusing standard solution $(1 \mu \mathrm{g} / \mathrm{mL})$ of the analytes by the built-in syringe pump at a flow rate of $10 \mu \mathrm{L} / \mathrm{min}$ combined with a makeup-flow of $60 \%(\mathrm{v} / \mathrm{v})$ methanol in $0.5 \mathrm{mmol} / \mathrm{L} \mathrm{pH} 3.0$ ammonium formate at a flow rate of $0.3 \mathrm{~mL} / \mathrm{min}$. The MRM transitions monitored were $\mathrm{m} / \mathrm{z}$ : 255 to 91 and 255 to 199 for daidzein, 271 to 153 and 271 to 215 for genistein and, 274 to 218 and 274 to 154 for genistein- $d_{3}$. The product ions at 91,153 and 218 were quantitative, while the product ions $\mathrm{m} / \mathrm{z} 199,153$ and 154 were qualitative. System control and data acquisition were achieved with the MassLynx 4.0.

Data processing and quantitation were performed by the QuanLynx Application Manager. For cortisone, cortisol-d4 was used as internal standard. Calibration was performed using a 6 points curve through linear regression with fit weighting to $1 / x^{2}$ to give higher priority to calibration points with a low concentration. The accepted range for ion ratios was within $20 \%$ of the calibration standards.

As low grade MDS patients present high apoptosis index in marrow cells, another point to check was if soy use would interfere with this index. Apoptotic rates were evaluated in five patients before and six months after soy use and in four normal controls. Apoptosis in CD34+ cells was determined in bone marrow (BM) mononuclear cells by flow cytometry using the annexin $\mathrm{V}$ and 7-actinomycin D method (Annexin FITC, CD34 PE - clone 8G12, 7AAD Becton-Dickinson, San Jose).
A historical control-group from the same institution was searched for each patient studied, matching for sex, age and MDS subtype in order to compare differences in blood cell counts due to the use of soy concentrate or to detect spontaneous increases that could not be credited to soy use. The same criteria for diagnosis were adopted to the control group. All historical controls data sheets were reviewed and special attention was paid to answers to inquires about clinical symptoms, transfusion needs, physical examination and laboratory results. Table 1 shows the control group data. No difference was found between control group and patients (Mann Whitney test) at the beginning of the study in respect to age $(p=0.81)$, Hb level $(p=0.42)$, neutrophil count $(p=0.72)$ and platelet count $(p=0.72)$. The Fisher test was used to compare patients and controls results at 3 , 6,9 and 12 months in relation to the proportion of response to those parameters.

\section{Results}

From the 14 MDS patients selected to the intervention study group: 8 completed one year of soy use, while 3 patients completed nine, six and three months, respectively. Three patients did not accomplish the minimum period of three-months, two of them due to disease complications culminating in death (case 2 - death due to sepsis, and case 14 - death due to bleeding) and one dropped out (case 9).

At the $3^{\text {rd }}$ month evaluation there were 11 patients in the study, 4 of which presented neutrophil response (cases 3, 5 7 and 8), and one of them concomitant platelet response (case 7). At the $6^{\text {th }}$ month evaluation, only 10 patients could be analyzed, since one died in the fourth month (case 6) due to sepsis. Except for case 7 who sustained platelet response only, all the others lost their initial responses. At the $9^{\text {th }}$ month evaluation, none out of nine patients showed any response. Case 10 died due to sepsis after the $6^{\text {th }}$ month. At the $12^{\text {th }}$ month evaluation there were 8 patients (case 8 dropped out at the $10^{\text {th }}$ month of follow-up) and only one presented neutrophil response (patient 5 who reacquired neutrophil response this time) (Table 2).

So, in the first evaluation, at 3 months, 4 out of 11 cases presented at least one of the response criteria. These patients were classified as refractory anemia with ringed sideroblasts (RARS) (cases 3, 5 and 7) and refractory cytopenia with multilineage dysplasia (RCMD) (case 8). Cases 3, 5 and 8 presented neutrophil response and case 7 showed neutrophil and platelet responses just in the first 
Characteristics of patients and controls studied: age, WHO subtype, IPSS, Hb level (initial, at $3^{\text {rd }} \mathrm{m}$ and $12^{\text {th }} \mathrm{m}$ ), neutrophil count (initial, $3^{\text {rd }} \mathrm{m}$ and $12^{\text {th }} \mathrm{m}$ ) and platelet count (initial, $3^{\text {rd }} \mathrm{m}$ and $12^{\text {th }} \mathrm{m}$ )

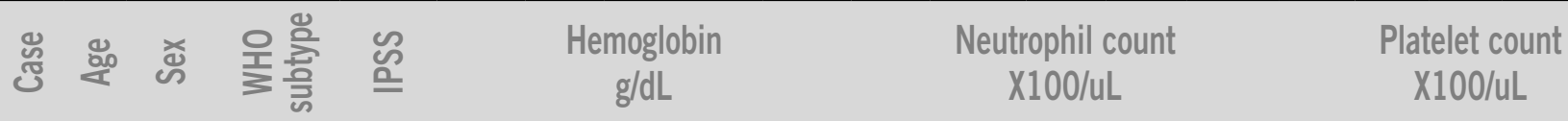

$\begin{array}{llllllllllllllllllllll}0 \mathrm{~m} & 3 \mathrm{~m} & 6 \mathrm{~m} & 9 \mathrm{~m} & 12 \mathrm{~m} & 0 \mathrm{~m} & 3 \mathrm{~m} & 6 \mathrm{~m} & 9 \mathrm{~m} & 12 \mathrm{~m} & 0 \mathrm{~m} & 3 \mathrm{~m} & 6 \mathrm{~m} & 9 \mathrm{~m} & 12 \mathrm{~m}\end{array}$

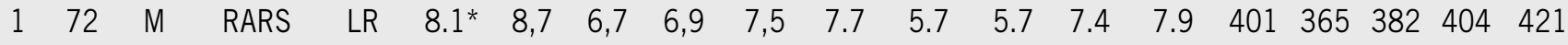

$273 \quad$ F $\quad$ RAEB-I Int-II 10.7

$1.4-59$

$\begin{array}{llllllllllllllllllll}3 & 79 & F & \text { RARS } & \text { LR } & 9.6^{*} & 10.0 & 9,7 & 8,2 & 8,9 & 1.5 & 2.3 & 1.8 & 1.2 & 1.5 & 185 & 263 & 185 & 237 & 247\end{array}$

$\begin{array}{llllllllllllllllllll}4 & 81 & F & \text { RA } & \text { LR } & 10.6 & 9,5 & 9,7 & 10,3 & 9,5 & 7.1 & 6.1 & 7.7 & 8.7 & 6.2 & 212 & 219 & 219 & 196 & 266\end{array}$

$\begin{array}{llllllllllllllllllll}5 & 71 & F & \text { RARS } & \text { LR } & 9.4^{*} & 10,3 & 7,6 & 7,7 & 7,2 & 1.3 & 2.3 & 1.6 & 1.4 & 2.0 & 209 & 177 & 200 & 164 & 192\end{array}$

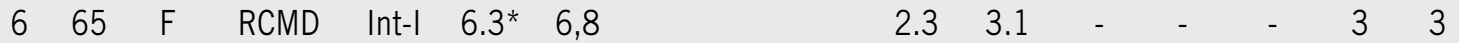

$\begin{array}{llllllllllllllllllll}7 & 70 & M & \text { RARS } & \text { LR } & 8.3^{*} & 8,6 & 8,8 & 8,4 & 8,2 & 0.9 & 2.1 & 2.8 & 2.5 & 0.8 & 54 & 85 & 170 & 70 & 48\end{array}$

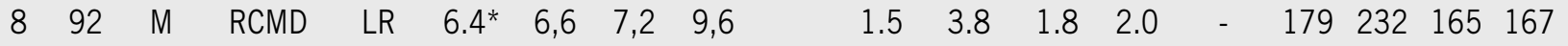

$981 \quad$ M $\quad$ RAEB-I Int-II 10.6

$0.7-\quad-\quad-\quad-169$

$1063 \quad M \quad$ RA LR $5.2 * 5,2 \quad 5,0$

$\begin{array}{lllllll}0.1 & 0.3 & 0.09 & - & - & 5 & 3\end{array}$

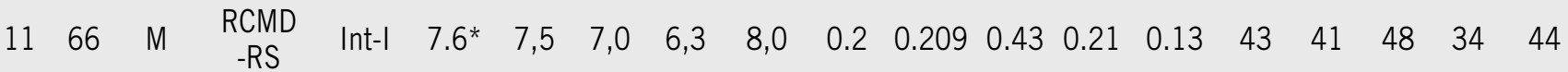

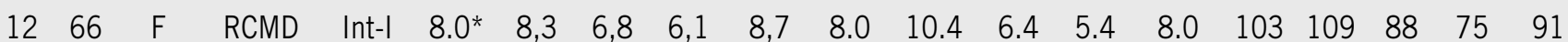

$\begin{array}{llllllllllllllllllll}13 & 66 & \text { F } & \text { RCMD } & \text { Int-I } & 9.5 & 10 & 8,4 & 9,0 & 9,1 & 0.18 & 2.6 & 3.0 & 2.7 & 3.3 & 139 & 167 & 160 & 156 & 179\end{array}$

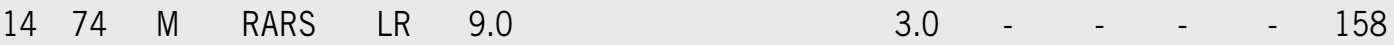

Control group

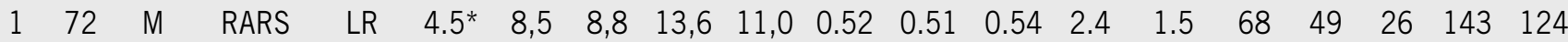

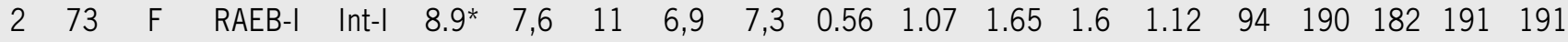

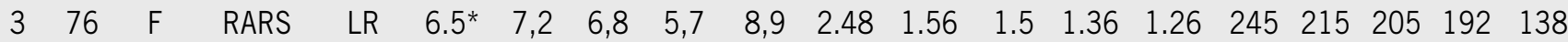

$\begin{array}{llllllllllllllllllll}4 & 83 & F & \text { RA } & \text { LR } & 11.3 & 11,8 & 11,3 & 10,3 & 10,2 & 2.04 & 1.32 & 2.04 & 1.75 & 2.08 & 330 & 270 & 330 & 244 & 255\end{array}$

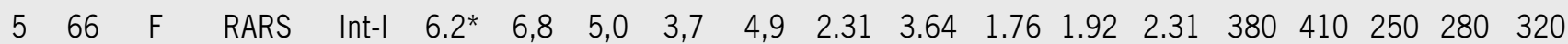

$\begin{array}{llllllllllllllllllll}6 & 61 & F & \text { RCMD } & \text { Int-I } & 4.3^{*} & 6,2 & 5,0 & 7,3 & 6,8 & 0.47 & 0.23 & 0.48 & 0.34 & 0.39 & 5 & 4 & 17 & 13 & 18\end{array}$

$\begin{array}{llllllllllllllllllll}7 & 71 & M & \text { RAEB-I } & \text { LR } & 5.8 * & 5,8 & 7,6 & 6,9 & 8,7 & 1.27 & 0.84 & 0.96 & 0.96 & 1.26 & 30 & 30 & 20 & 18 & 9\end{array}$

$\begin{array}{llllllllllllllllllll}8 & 85 & M & \text { RCMD } & \text { LR } & 11.8 & 9,8 & 11,2 & 10,9 & 11,7 & 5.63 & 2.45 & 2.47 & 1.62 & 1.8 & 121 & 72 & 110 & 72 & 99\end{array}$

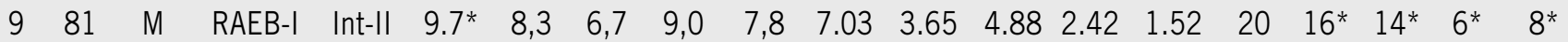

$\begin{array}{llllllllllllllllllll}10 & 63 & M & \text { RA } & \text { LR } & 9.5^{*} & 9,5 & 9,6 & 11,5 & 12,9 & 1.65 & 1.25 & 1.19 & 1.51 & 1.45 & 110 & 109 & 137 & 159 & 158\end{array}$

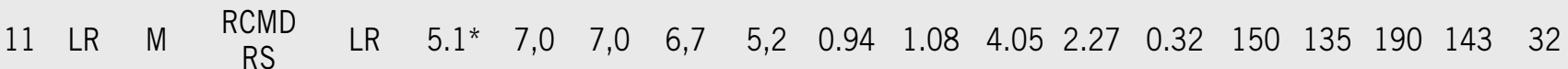

$\begin{array}{llllllllllllllllllll}12 & 61 & F & \text { RCMD } & \text { LR } & 13.2 & 13,5 & 13,8 & 13,7 & 13,2 & 1.08 & 1.14 & 2.39 & 1.22 & 1.60 & 65 & 75 & 98 & 91 & 125\end{array}$

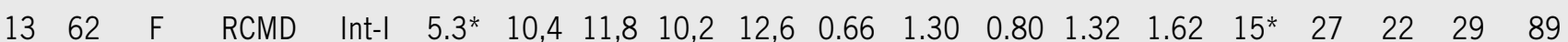

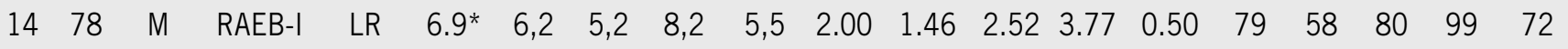

M: male; F: female; RA: refractory anemia; RARS: refractory anemia with ringed sideroblasts; RCMD: refractory cytopenia with multilineage dysplasia; RCMD and RS: refractory cytopenia with multilineage dysplasia and ringed sideroblasts; RAEB-I: refractory anemia with excess of blasts I; IPSS: International Prognostic Scoring System; LR: low risk; Int-I: intermediate I; Int-II: intermediate II.

* = transfusion-dependent; bold = means when response criteria were met. 


\section{Table 2 Responses of all patients and controls during the study period}

\begin{tabular}{|c|c|c|c|c|}
\hline \multirow{2}{*}{ Cases } & \multicolumn{4}{|c|}{ Results } \\
\hline & $3^{\text {rd }}$ month & $6^{\text {th }}$ month & $9^{\text {th }}$ month & $12^{\text {th }}$ month \\
\hline 1 & No response & No response & No response & No response \\
\hline 2 & Death & & & \\
\hline 3 & Neutrophils increase & No response & No response & No response \\
\hline 4 & No response & No response & No response & No response \\
\hline 5 & Neutrophils increase & No response & No response & Neutrophils increase \\
\hline 6 & No response & Death & & \\
\hline 7 & $\begin{array}{c}\text { Neutrophils and } \\
\text { platelets increases }\end{array}$ & Platelet increase & No response & No response \\
\hline 8 & Neutrophils increase & No response & No response & Dropped out \\
\hline 9 & Dropped out & & & \\
\hline 10 & No response & No response & Death & \\
\hline 11 & No response & No response & No response & No response \\
\hline 12 & No response & No response & No response & No response \\
\hline 13 & No response & No response & No response & No response \\
\hline 14 & Death & & & \\
\hline & & Control grou & & \\
\hline 1 & No increase & No increase & $\begin{array}{l}\text { Neutrophils and } \\
\text { Platelets increase }\end{array}$ & No increase \\
\hline 2 & Neutrophils increase & Neutrophils increase & No increase & No increase \\
\hline 3 & No increase & No increase & No increase & No increase \\
\hline 4 & No increase & Neutrophil increase & No increase & No increase \\
\hline 5 & No increase & No increase & No increase & No increase \\
\hline 6 & No increase & Platelets increase & No increase & No increase \\
\hline 7 & No increase & No increase & No increase & No increase \\
\hline 8 & No increase & No increase & No increase & No increase \\
\hline 9 & No increase & No increase & No increase & No increase \\
\hline 10 & No increase & No increase & No increase & No increase \\
\hline 11 & No increase & Neutrophils increase & No response & No increase \\
\hline 12 & No increase & Neutrophils increase & No increase & No increase \\
\hline 13 & Neutrophils increase & Neutrophils increase & No increase & No increase \\
\hline 14 & No increase & No increase & No increase & No increase \\
\hline
\end{tabular}

trimester. However, when we applied the same response criteria to control group we found that during the same period, two control patients also presented spontaneous increase in neutrophil counts ( $36 \%$ versus $14.28 \%, p=0.35$,
Fisher) (Table 2). Applying the same criteria to patients and controls at the 6,9 and 12 month evaluations no differences ( $10 \%$ versus $42.8 \%, p=0.17 ; 0 \%$ versus $7 \%$, $p=1.0 ; 12.5 \%$ versus $0 \%, p=0.36$, respectively) were 
detected (Table 2). Thus the increase observed in blood counts may have been due to spontaneous variations during the follow up, therefore the soy concentrate can not be implicated as a contributing factor to blood count increases, notwithstanding the sample size that was small.

During the study period no transfusion dependent patient became independent or presented a reduction in more then $50 \%$ of their transfusion needs.

The plasmatic levels of genistein and dadizen were increased as compared to stating levels by LC-MS/MS dosage ( $p=0.016$, t-Test).

The rate of apoptosis on BM CD34+ cells before the soy use were $72 \%, 69.3 \%, 79.9 \%, 77 \%$ and $40.7 \%$ in cases $3,4,5,7$ and 12 , respectively (mean rate of $68.6 \%$ ). The mean level of apoptosis on normal controls was $41.7 \%$ (29.6\%-49\%) ( $p=0.08)$. Four patients presented reduction of apoptotic levels (cases 3, 5, 7 and 12) after six months of soy use and one patient presented an increase of CD34+ cells annexin positivity (case 4). The apoptotic rate after soy use was 36\% (case 3), 85\% (case 4), 65\% (case 5), 62\% (case $7)$ and $28 \%$ (case 12$)(p=0.5)$. Interestingly, although three patients $(3,5$ and 7$)$ with apoptosis reduction presented increase of neutrophils during soy use this was not significant.

\section{Discussion}

This study was designed to find out if a standardized soy concentrate used as a dietary supplementation during an established period of time, by a group of MDS patients not eligible to specific drugs therapies, could offer benefits in improvement of hematologic counts, like hemoglobin concentration, neutrophil and platelet counts.

Considering that improvements in cytopenias is a goal in the therapeutic intervention of low or intermediate-risk MDS patients, the intention in the present study was to find out if the soy concentrate would result in any response. The responses criteria were established according to previous reports ${ }^{(6)}$.

The use of a soy concentrate in a standardized manner induced an increase of neutrophil and/or platelet counts in $28.5 \%$ of patients as compared to their own values at the start of the study (Table 1). Most of the responses occurred during the first trimester of use (Table 2).

Considering side effects related possibly to soy use, one patient complained of nausea and vomiting, another one of dark feces and one presented an acute gastroenterocolitis crisis, all of them isolated episodes, at the $5^{\text {th }}, 6^{\text {th }}$ and $6^{\text {th }}$ months of use of soy concentrate, respectively. The control group did not present any of these complains. The adverse effects detected were sporadic and possibly unrelated to soy supplement use.

No vitamin supplementation or therapy was used during the period the patient was in the study. In general, patients' adherence to the study was good, except for two who dropped out due to intolerance to the taste of soy.

There were four deaths during the study. The number of deaths was expected as the natural history of the disease. In fact, IPSS median survival estimation for low-risk, intermediate 1 and 2 patients are: 5.7 years, 3.5 and 1.2 years, respectively ${ }^{(8)}$. In the intervention group patients died in accordance to these estimations (case 2 in 3.25 years versus expected 1,2; case 6 in 3.5 versus 3.5; case 10, 5.1 versus 5.7) except for case 14 who died 18 days after starting the protocol due to a peptic ulcer bleeding, though with normal platelet counts, 9 months after diagnosis an with an expected survival of 5.7 years.

Apoptosis is an interesting phenomenum in MDS, contribuiting to cytopenias, specially in low risk MDS. The reduced apoptosis observed in four cases indicates that there may be a role to soy in this pathway but more detailed studies must be conduct to clear out this aspect.

There were no Japanese patients in the study or control group. There are several reports indicating differences in clinical features between Asian MDS patients and Western ones: the prevalence of MDS in United States is higher when compared with Japan ${ }^{(21,24)}$; the median age in Asian countries patients is around 60 versus 68-73 in Western ones ${ }^{(17) ;}$ the RA subtype is more frequent in Asian while the RARS is rarer as compared to Western ones ${ }^{(17)}$; considering prognosis, Japanese patients were significantly more favorable than that of German patients and Japanese patients had a significantly lower cumulative risk of acute leukemia evolution than did German patients ${ }^{(17)}$. The reasons for these differences are unknown. Besides ethnic origins, one of the major differences in diet between these populations is that Asian people traditionally consume a diet rich in soy products. These data suggest that a diet rich on soy products may contribute to avoid the occurrence of cancer.

No benefit was found in this preliminary study implicating soy as a contributing factor to blood count increases.

\section{Acknowledgments}

The authors would like to thank EMBRAPA and Instituto Fleury for assistance. 


\section{References}

1. AKIYAMA, T. et al. Genistein, a specific inhibitor of tyrosinespecific protein kinases. J Biol Chem, v. 262, n. 12, p. 5592-5, 1987.

2. BANDELE, O. J.; OSHEROFF, N. Bioflavonoids as poisons of human topoisomerase II alpha and II beta. Biochemistry, v. 46, n. 20, p. 6097-108, 2007.

3. BENNETT, J. M. et al. Proposals for the classification of the myelodysplastic syndromes. Br J Haematol, v. 51, n. 2, p. 189-99, 1982.

4. BLOEDON, L. T. et al. Safety and pharmacokinetics of purified soy isoflavones: single-dose administration to postmenopausal women. Am J Clin Nutr, v. 76, n. 5, p. 1126-37, 2002.

5. CHEN, A. C.; DONOVAN, S. M. Genistein at a concentration present in soy infant formula inhibits Caco-2BBe cell proliferation by causing G2/M cell cycle arrest. J Nutr, v. 134, n. 6, p. 1303-8, 2004.

6. CHESON, B. D. et al. Report of an international working group to standardize response criteria for myelodysplastic syndromes. Blood, v. 96, n. 12, p. 3671-4, 2000.

7. $\mathrm{CHOI}, \mathrm{S}$. Y. et al. Estrogenic activities of isoflavones and flavones and their structure-activity relationships. Planta Med, v. 74, n. 1, p. 25-32, 2008.

8. GREENBERG, P. et al. International scoring system for evaluating prognosis in myelodysplastic syndromes. Blood, v. 89, n. 6, p. 2079-88, 1997.

9. GUO, J. M. et al. Effect of daidzein on cell growth, cell cycle, and telomerase activity of human cervical cancer in vitro. Int J Gynecol Cancer, v. 14, n. 5, p. 882-8, 2004.

10. HARRIS, N. L. et al. World Health Organization classification of neoplastic diseases of the hematopoietic and lymphoid tissues: report of the Clinical Advisory Committee meeting-Airlie House, Virginia, November 1997. J Clin Oncol, v. 17, n. 12, p. 3835-49, 1999.

11. HIRAI, H. Molecular pathogenesis of MDS. Int J Hematol, v. 76, p. 213-21, 2002.

12. HOFMANN, W. K. et al. Therapeutic spectrum in the treatment of myelodysplastic syndromes. Expert Opin Pharmacother, v. 5, n. 12, p. 2451-8, 2004.

13. KIURU, P. S.; WÄHÄLÄ, K. Expedient microwave deuteration of estrone in CF3COOD. Tetrahedron Lett, v. 43, p. 3411-2, 2002.

14. LIAN, F. et al. p53-independent apoptosis induced by genistein in lung cancer cells. Nutr Cancer, v. 33, n. 2, p. 125-31, 1999.

15. LIGGINS, J. et al. Daidzein and genistein content of cereals. Eur J Clin Nutr, v. 56, n. 10, p. 961-6, 2002.

16. LO, F. H.; MAK, N. K.; LEUNG, K. N. Studies on the antitumor activities of the soy isoflavone daidzein on murine neuroblastoma cells. Biomed Pharmacother, v. 61, n. 9, p. 591-5, 2007.

17. MATSUDA, A. et al. Difference in clinical features between Japanese and German patients with refractory anemia in myelodysplastic syndromes. Blood, v. 106, p. 2633-40, 2005.
18. PETERSON, G.; BARNES, S. Genistein and biochanin A inhibit the growth of human prostate cancer cells but not epidermal growth factor receptor tyrosine autophosphorylation. Prostate, v. 22, n. 4, p. 335-459, 1993.

19. PETERSON, G.; BARNES, S. Genistein inhibition of the growth of human breast cancer cells: independence from estrogen receptors and the multi-drug resistance gene. Biochem Biophys Res Commun, v. 179, n. 1, p. 661-7, 1991.

20. REINLI, K.; BLOCK, G. Phytoestrogen content of foods: a compendium of literature values. Nutr Cancer, v. 26, n. 2, p. 123-48, 1996.

21. ROLLISON, D. E. et al. Epidemiology of myelodysplastic syndromes and chronic myeloproliferative disorders in the United States, 2001-2004: utilizing data from the NAACCR and SEER programs. Blood, v. 112, n. 1, p. 45-52, 2008.

22. ROMEO, M. et al. Comparision of cytogenetics with FISH in 40 myelodysplastic syndrome patients. Leuk Res, v. 26, n. 11, p. 993-6, 2002.

23. SARKAR, F. H.; LI, Y. Soy isoflavones and cancer prevention. Cancer Invest, v. 21, n. 5, p. 744-57, 2003.

24. SHIMIZU, H. et al. Prevalence of the myelodysplastic syndromes in Japan. Int J Hematol, v. 61, n. 1, p. 17-22, 1995.

25. THOMAS, B. F. et al. Quantitative analysis of the principle soy isoflavones genistein, daidzein and glycitein, and their primary conjugated metabolites in human plasma and urine using reversed-phase high-performance liquid chromatography with ultraviolet detection. J Chromatogr B Biomed Sci Appl, v. 760, n. 2, p. 191-205, 2001.

26. TRICOT, G. J. Complications and treatment of the myelodysplastic syndromes. Leuk Res, v. 16, n. 1, p. 117-21, 1992. 